Valóságos könyvtár - könyvtári valóság. Könyvtár- és információtudományi tanulmányok 2016. Szerk. Kiszl Péter, Boda Gáborné Köntös Nelli.

Budapest, ELTE BTK Könyvtár- és Információtudományi Intézet. 2017. 39-45.

\title{
VÁLTOZÁSOK, IRÁNYOK A MAGYARORSZÁGI FELSÖOKTATÁSI KÖNYVTÁRAKBAN
}

\author{
SZÉKELYNÉ TÖRÖK TÜNDE
}

ELTE Egyetemi Könyvtár Gyűjteményszervezési Osztály, osztályvezető

\begin{abstract}
ABSZTRAKT
Az elmúlt néhány évtizedben a könyvtárakkal szemben megfogalmazott elvárások a külső körülmények átalakulásával párhuzamosan jelentősen módosultak. A hagyományos munkafolyamatok átalakulnak, a könyvtári tevékenységek sorában a hangsúlyok áthelyeződnek, új szolgáltatások születnek. Az egyetemek között kialakult versenyhelyzetben fontos kérdés, hogy a könyvtáraik mennyire képesek a jogszabályokban meghatározott feladataikat rugalmasan, a mindenkori igényekhez alkalmazkodva ellátni, miközben a tőlük telhető leghatékonyabb módon támogatják az egyetem stratégiai céljait és a kutatást is. A könyvtár ügyfeleinek és a könyvtárosok kommunikációjának színterei, a papíralapú és elektronikus állománygyarapítás módszerei, a gyűjtött, feltárt és tárolt dokumentumok jellege, a feldolgozásuk folyamata - a teljesség igénye nélkül néhány munkafolyamat azok közül, melyek átalakulása a mindennapok része. Mindeközben módosul a hagyományos szemlélet is: a dokumentumközpontúság helyére egyre inkább az adat- és információszolgáltatás kerül, mely gyakran stratégiai jelentőséggel bír.
\end{abstract}

Valamennyien találkozhattunk már a könyvtáros szakma jövőjével kapcsolatos, bizonytalanságot tükröző gondolatok megfogalmazásával $(, \ldots$ nem tudjuk, hogyan alakul a könyvtáros szakma...” „... mi lesz egy évtized múlva a jelenlegi könyvtárak szerepe...”1) mind az elektronikus, mind a nyomtatott sajtó hasábjain, vagy szakmai diskurzusokon. Van-e alapja az aggodalmaskodó szavaknak, meghatározható-e a változó környezetben a felsőoktatási könyvtárak átalakuló funkciója?

\section{Felsőoktatási könyvtárak a statisztikák tükrében}

Ha ezekről az intézményekről és a jelenlegi helyzetükről szeretnénk képet alkotni, célszerű az objektív számadatokhoz fordulnunk: a személyes, illetve a távhasználatok száma fontos mutató lehet a felsőoktatási könyvtárak szerepének elemzéséhez. 


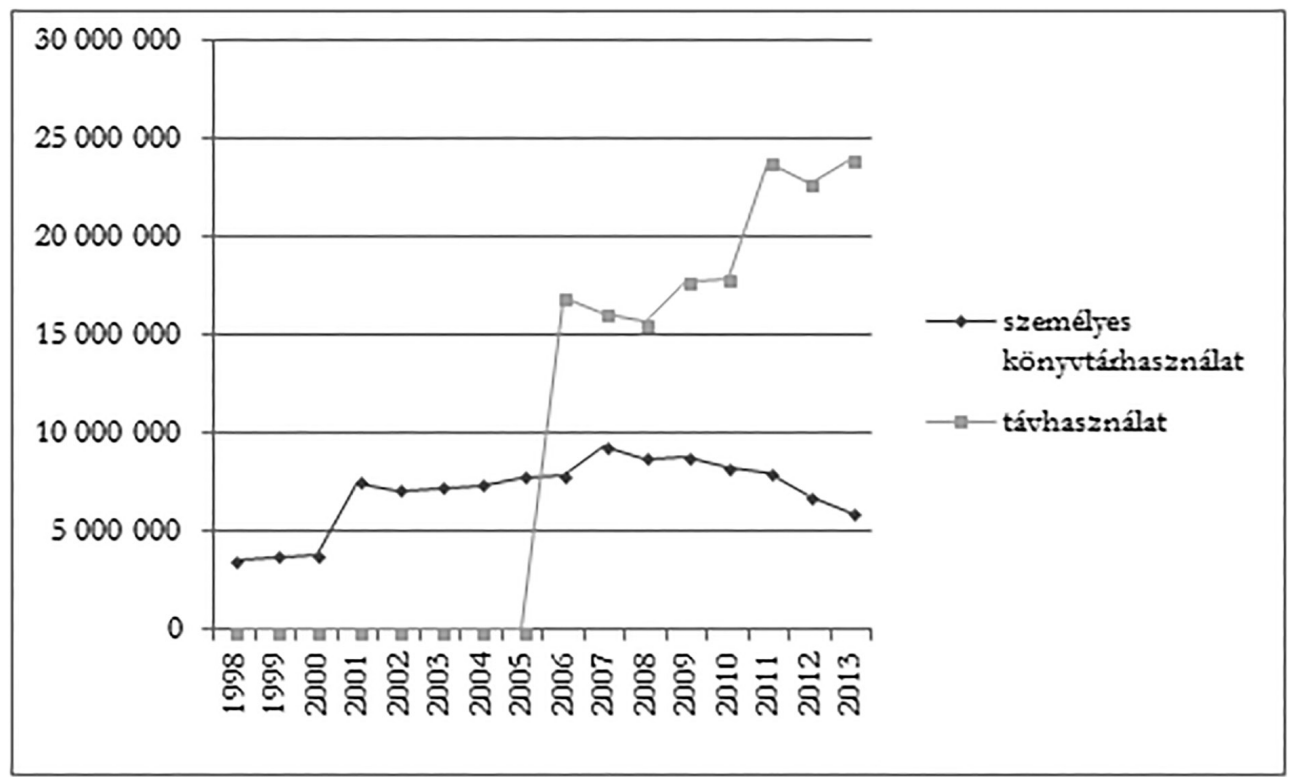

1. ábra: A felsöoktatási könyvtárak személyes-és távbasænálatának alakulása 1998-2013 köäött

A Könyvtári Intézet statisztikai adatai alapján készített grafikonon (1. ábra) látható, hogy amíg a személyes használat csökkenő tendenciát mutat, addig a távhasználatok száma dinamikusan növekszik. Mindannyian tudatában vagyunk annak, hogy a statisztikai adatok korlátozottan precízek és „,csak bizonyos megbízhatósági szinten és hibahatárral jellemzik" a kiválasztott tevékenységet. ${ }^{3}$ Ezúttal azonban még erősebb kétségeinket kell megfogalmaznunk: 2015 elején a könyvtárosok levelezólistáján zajlott vita éppen az adatszolgáltatások idején bontakozott ki azzal kapcsolatban, hogy a YouTube-on elérhető, a könyvtár szolgáltatásait népszerűsítő film megnyitása beleértendő-e a kért adatkörbe és mi a teendő, ha ugyanez a kisfilm a könyvtár portáljáról érhetô el. Talán most nem is az a lényeg, hogy mi lett a vita végkicsengése, hogy egyáltalában sikerült-e közös álláspontra jutniuk a hozzászólóknak, hanem sokkal inkább az, hogy láthattuk, az intézmények mennyire eltérően értelmezik a távhasználat fogalmát és ebből következően azt gondolhatjuk, hogy a szolgáltatott tartalom is különböző.

A használati statisztikával kapcsolatos következő kritikai megjegyzés az MTMT (Magyar Tudományos Múvek Tára) adatbázisának építéséhez kapcsolódik: a könyvtárosok által tartott, az adatbázis használatát bemutató előadások, a publikációs jegyzékek rögzítése, javítása, idézettségkeresés, az ellenőrzések folyamata során azok az egyetemi polgárok is kapcsolatba kerülnek a könyvtárakkal, akik nem beiratkozott olvasók. Ők mint könyvtárhasználók nincsenek nyilvántartva a hivatkozott adatsorban.

Mivel a statisztikai mutatók nem tükrözik pontosan a felsőoktatási könyvtárakra jellemző folyamatokat, eredményesebb lehet a hagyományos tevékenységek átalakulásá- 
nak, a hangsúlyok áthelyeződésének és az új szolgáltatások megjelenésének áttekintése a teljesség igénye nélkül.

\section{Szerzeményezés, gyüjtemény és tudásvagyon menedzselése}

Amerikai és németországi felsőoktatási könyvtárakban több példát is láthatunk arra, hogy a beszerzendő dokumentumokat teljes egészében a könyvtár használói határozzák meg. A DDA (demand-driven acquisition) módszer lényegéhez tartozik emellett a gyorsaság is: a megrendeléstôl számított néhány napon belül a dokumentum már az olvasó rendelkezésére áll. Magyarországon pozitív példaként említhető a Budapesten múködő CEU (Central European University) gyakorlata, ahol a hallgatók kutatásaihoz szükséges szakirodalmat teljes körűen beszerzik. Az eljárásmód szélesebb körben való hazai alkalmazásának gátat szab a felsőoktatási könyvtárak szűkös költségvetése, valamint az egyetemekre jellemző bürokratikus ügyintézés, ami több héttel is megnövelheti a vásárlás folyamatát. A hátráltató tényezők ellenére az ELTE központi könyvtára az Aleph integrált rendszerén keresztül indítható dezideráta szolgáltatás bevezetésén dolgozik jelenleg, amelynek előfeltétele az informatikai problémák megoldásán túl a megfelelő beszerzési keret biztosítása és egy egységes, az ELTE valamennyi könyvtárára érvényes szabályrendszer kidolgozása.

A beszerzések módjának átalakulása mellett változott a gyűjtött dokumentumtípusok köre, illetve a hordozó. Az időszaki kiadványok jelentős része online vagy online is elérhető, a papíralapú könyvek mellett megnövekedett az e-könyvek száma. Robbanásszerű elterjedésükről azonban semmiképpen nem beszélhetünk: az akadályt jelentő tényezők között meg kell említenünk, hogy Magyarországon az elektronikus vagy digitális kiadványokat 27\%-os ÁFA terheli, míg a nyomtatott verzió kedvezményes, 5\%-os ÁFA kulcs alá tartozik. Az adatbázisok a felsőoktatási könyvtárak alapvető feladatát, az oktatás, a kutatás szolgálatát támogatják. Az Oktatási Minisztérium 2001-ben azzal a céllal indította az Elektronikus Információszolgáltatás (EISZ) programot, hogy megteremtse a kutatói, oktatói információs infrastruktúra alapjait. A projekt 2009-ig központi finanszírozású volt, ezt követően az állami források mellett megjelent az intézményi önrész. Az új fizetési modell bevezetésével párhuzamosan markáns változás történt a célközönsége körében is, amely kibővült a közkönyvtárakkal.

Előtérbe került a teljes szövegű tudományos közlemények, a képi dokumentumok archiválásának, metaadatolásának és szolgáltatásának kérdése. Az egyetemek tudásvagyonának reprezentálása, az intézmény tudományos publikációinak, kutatási eredményeinek nyilvántartása és archiválása, a PhD-dolgozatok közzététele, az oktatási anyagok, valamint az úgynevezett szürke irodalom körébe tartozó dokumentumok tárolása, szolgáltatása céljából a felsőoktatási intézmények többsége létrehozta a saját repozitóriumát. A HUNOR (HUNgarian Open Repositories) tagjai egy közös keresőfelületet alakítottak ki annak érdekében, hogy a tudományos eredmények hazai és nemzetközi ismertségét hatékonyan javítsák. 


\section{Digitalizálás}

A digitalizálás legfontosabb indoka az állományvédelem mellett az archiválás, a kulturális örökség megőrzése és a szélesebb használói kör számára való hozzáférés biztosítása. A felsőoktatási intézmények könyvtárai saját egyetemük szellemi és tárgyi objektumai mellett elsősorban azokat a gyújteményeiket digitalizálják, melyek különleges értéket képviselnek, és nem esnek a szerzői jogi szabályozás hatálya alá.

Az ELTE Egyetemi Könyvtár digitalizálási tervében is elsőbbséget élveznek a kéziratgyújtemény és a 20. század előtti dokumentumgyűjtemény unikális darabjai: a 8000 egységből álló grafika anyag és a Hevenesi - Kaprinai - Pray kollekció a Nemzeti Kulturális Alap (NKA) pályázatán kapott támogatás segítségével elsóként került be az ELTE repozitóriumába. A kisnyomtatványok feldolgozása és digitalizálása 2011-ben kezdődött és a folyamatos munka eredményeként a 35000 darabból álló gyűjteménynek jelenleg mintegy harmada érhető el az ELTE elektronikus katalógusán keresztül.

\section{Feldolgozás, csatlakozás adatbázisokhoz.}

Az integrált könyvtári rendszerek megjelenésével megteremtődtek a feltételei a számítógépes együttmúködésnek: a könyvtárak közötti adatcserével megvalósulhat az egyszeri feldolgozás, többszöri felhasználás elve. A központi számítógépes szolgáltatások alapja a géppel olvasható katalogizálás, a MARC-formátum (MAchine Readable Cataloguing), ugyanakkor a közös katalogizálási szabályok alkalmazása is elengedhetetlen feltételként említhető. Áttekintve a hazai szabványok és szabályzatok rendszerét, megállapíthatjuk, hogy a szabályozatlan területek mellett elavult, sokszor egymásnak ellentmondó előírások vonatkoznak egy-egy könyvtári munkafolyamatra, az irányelvek nincsenek összhangban a nemzetközi tendenciákkal. Mindez arra kényszeríti a könyvtárakat, hogy úgynevezett házi szabályzatokat gyártsanak, ami az erőforrások pazarlásán túl az egységesség elvét csak az adott intézményen belül biztosíthatja. Az említett problémák a MOKKA-ban (Magyar Országos Közös Katalógus) is tükröződnek: például ugyanarról a dokumentumról több rekord betöltődik az adatbázisba abban az esetben, ha a duplumellenőrzés során a rendszer 110 karakterből álló duplumkulcsa eltérést érzékel.

A MOKKA egyúttal a könyvtári dokumentumok lelőhely-nyilvántartását is magában foglalja, az ODR (Országos Dokumentumellátási Rendszer) a könyvtárközi dokumentumellátást biztosítja. A felsőoktatási intézmények aktivitása e téren évrôl évre csökken, bár a küldött dokumentumszám még mindig meghaladja a kért kiadványok számát. Mindez arra enged következtetni, hogy ezek a könyvtárak olyan gyűjteményekkel rendelkeznek, melyek máshol nem, vagy csak elvétve lelhetők fel (2. ábra). 


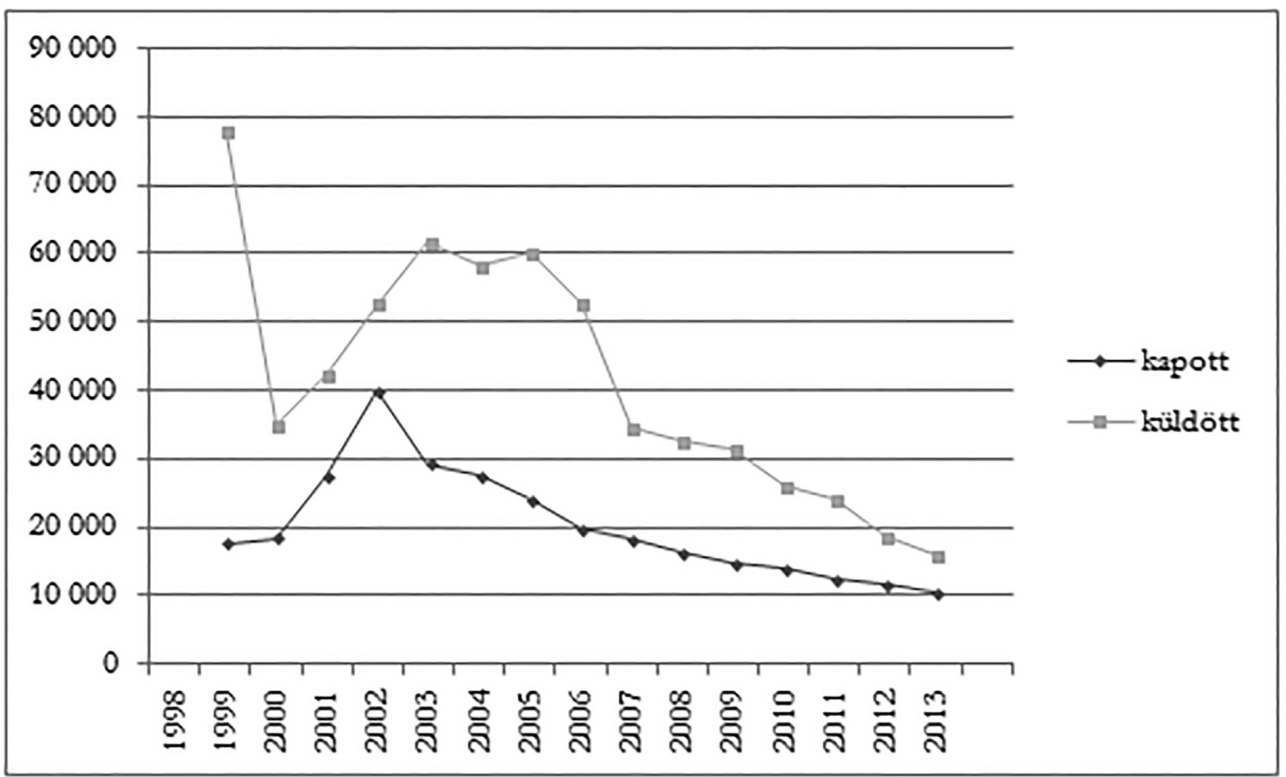

2. ábra: A felsöoktatási könyvtárak könyvtárkö̈zi kölcsönzésben való részvétele 1998-2013 közö̈tt

Az OSZK tárgyalásokat kezdett az OCLC-vel (Online Computer Library Center) annak érdekében, hogy a MOKKA állománya bekerüljön a WorldCat adatbázisába. A megállapodás időpontja egyelőre nem ismert, pedig stratégiai jelentőségű kérdésről van szó: jelenleg a magyar tartalom, a magyar irodalom, a magyar nyelvű tudomány jelenléte a világkatalógusban nemzetközi viszonylatban minimális.

A MaNDA (Magyar Nemzeti Digitális Archívum és Filmintézet) által koordinált közfoglalkoztatási programhoz levéltárak, múzeumok mellett könyvtárak is csatlakoztak: a digitalizált dokumentumok és metaadataik feltöltése részben folyamatos, részben az úgynevezett kötegelt feltöltés módszerével válnak elérhetővé. Ez utóbbi eljárás informatikai megoldása a közeli hónapokban várható, ezt követően közel egymillió rekorddal bővül az archívum állománya. Ezzel párhuzamosan a MaNDA adatokat szolgáltat az európai digitális adatbázis, a Europeana számára.

\section{Szolgáltatás}

A hagyományos könyvtári feladatok (a már létezô dokumentumok, publikációk beszerzése, gyűjtése szolgáltatása és őrzése) helyett egyre inkább előtérbe kerül az intézmény kutatómunkájának támogatása, a szerzők publikációs tevékenységének segítése. A Szegedi Tudományegyetem Klebelsberg Könyvtár kifejezetten ilyen céllal hozta létre az SZTE Szerzői Eszköztár elnevezésű szolgáltatását.

Jellemző tendencia a könyvtárak nyitva tartási idejének jelentős megnövelése: a Semmelweis Egyetem Központi Könyvtára például a hét minden napján (munkaszüneti napokon is) 24 órában várja az intézmény dolgozóit és hallgatóit. A könyvtárak nemcsak 
a tanuláshoz szükséges forrásokat szolgáltatják, hanem biztosítják a megfelelő tanulási teret is, maguk is képzőhelyekké válnak.

\section{Változások, irányok}

Ha a kört kitágítjuk és a jellemző változásokat, irányokat a szakkönyvtárak vonatkozásában is vizsgáljuk, néhány, országos jelentőségű projektet kell megemlítenünk.

- ALIADA (Automatic Publication Under Linked Data Paradigm of Library Data) projekt: A Szépművészeti Múzeum könyvtárában zajló program fő célkitűzése, hogy feloldja a múzeumi és könyvtári rendszerek zártságát, biztosítsa adataik automatikus közzétételét a szemantikus weben egy nyílt forráskódú szoftver létrehozásával.

- Nemzeti névtér létrehozása: az OSZK koordinálásával alakuló bizottság tevékenységébe már több felsőoktatási intézet is bekapcsolódott.

- Crowdsourcing: a közösségekben, a tömegben (crowd) rejlő tudást hasznosítva képes hatékony megoldásokat találni egy-egy megfogalmazott kérdéskör vagy probléma megoldására. A könyvtári területeken kevéssé kihasznált lehetőség alkalmazása például fotókon szereplő emberek és helyek azonosítására, kéziratos anyagok begépelésére, az optikai karakterfelismerés hibáinak javítására képzelhető el.

- Big Data: a felsőoktatási intézményben elóállított nagy mennyiségű adat strukturált kezelését jelenti, melynek tárolása, integrálása, elemzése, szolgáltatása hozzájárulhat a versenyképesség növeléséhez.

- A könyvtárakban dolgozók köre jelentősen módosult: a szakalkalmazottak (könyvtárosok, informatikusok, restaurátorok, könyvkötők stb.) mellett hallgatók, önkéntesek és közfoglalkoztatottak is részt vesznek a napi munka ellátásában.

- További kérdés, hogy az elektronikus tananyagok tárolása, archiválása és hozzáférhetővé tétele területén a felsőoktatási intézmények könyvtárai milyen szerepet vállaljanak.

\section{Országos feladatok ellátása}

A felsőoktatási intézmények könyvtárai és a szakkönyvtárak több esetben országos feladatok ellátására vállalkoztak. A Miskolci Egyetem, Könyvtár, Levéltár, Múzeum 2002 óta építi a MATARKA-t (Magyar folyóiratok tartalomjegyzékeinek kereshetô adatbázisa). Többnyire Magyarországon megjelenő tudományos és szakmai folyóiratok tartalomjegyzékeit dolgozza fel, elvezet a kiválasztott folyóiratok honlapjára, hozzáférést ad ugrópontok segítségével a cikkek teljes szövegéhez, ha azok szabadon elérhetők az interneten. Közvetítésével a cikkek másolata megrendelhető az OSZK-tól.

A Magyar Tudományos Művek Tára (MTMT) 2009-ben kezdte meg a múködését az MTA Elnökségének határozata alapján. Létrehozásának célja a hazai tudományos kutatás eredményeinek hiteles nyilvántartása. Az MTA tagintézményeinek együttműködésével indított programhoz folyamatosan csatlakoztak az egyetemek, a projektgazda az MTA Könyvtár és Információs Központ. 2015. július 13-tól az MTMT múködését a módosított MTA törvény szabályozza. 
A HUNGARICANA közgyűjteményi portál üzemeltetője az Országgyűlési Könyvtár és Budapest Főváros Levéltára. A portál kivitelezője az Arcanum Adatbázis Kft. Fő törekvése a nemzeti gyűjteményekben (könyvtár, levéltár, múzeum) fellelhető kultúrkincsek, történelmi dokumentumok hozzáférhetôvé tétele.

\section{Összegzés}

Látható, hogy a rendszerben egyszerre van jelen a forráshiány és a párhuzamosságokból eredő pazarlás. Ki vagy mi lehet az ellentmondás feloldásának kulcsa? Részben a mindenkori kormányzattól várhatunk támogatást, másrészt jogosan tartunk igényt az Országos Széchényi Könyvtár koordináló szerepének markánsabb érvényesítésére. De megoldást kínálhat a Berlinben 2015 ôszén rendezett konferencián (Staff Training Days Library, Humboldt Egyetem) megfogalmazott gondolat is: sok esetben gyors és hatékony eredmény születhet a régió vezető egyetemi könyvtárainak közvetlen együttműködésével.

\section{Irodalom}

HAJNAL WARD Judit: A változások menedzselése a felsőoktatási könyvtárakban. = Könyvtári Figyelő, 19. (55.) évf. 2. sz. 2009. 280-283. p.

HORVÁTH Ádám: Könyvtári és múzeumi adatok automatikus publikálása a szemantikus webenaz ALIADA projekt jelenlegi állása. Forrás: https://videotorium.hu/hu/recordings/[-] details/10396,Konyvtari_es_muzeumi_adatok_automatikus_publikalasa_a_szemantikus[-] _weben_-_az_ALIADA_projekt_jelenlegi_allasa [2016. február 28.]

LIGETI Csák: Statisztikusok egymás között: számábrázolási pontosság a statisztikai tájékoztatásban. Forrás: http://www.ksh.hu/statszemle_archive/2000/2000_05/2000_05_384.pdf [2016. február 13.]

A magyarországi könyvtárak statisztikai adatai. Forrás: http://ki.oszk.hu/content/statisztika [2016. február 28.]

A MaNDA megkezdte az adatexportot az Europeana felé. Forrás: http://mandarchiv.hu/cikk/[-] 2802/A_MaNDA_megkezdte_az_adatexportot_az_Europeana_fele [2016. február 25.]

MARC Standards. Forrás: https://www.loc.gov/marc [2016. február 28.]

SZTE Szerzői Eszköztár. Forrás: http://szerzoknek.ek.szte.hu [2016. február 25.]

Székelyné Török Tünde az ELTE Egyetemi Könyvtár Gyűjteményszervezési Osztályának vezetője, a Könyvtári Tanács tagja, az Egyetemi Könyvtári Szolgálat IKR Koordinációs Bizottság Formai Almunkabizottságának vezetője. 